El-Meouch Nedim Márton - Alpek B. Levente

\title{
A magyarországi bankfiókhálózat területi elhelyezkedésének és klasztereződésének vizsgálata az európai bankfiókbezárási trend közepette 2020-ban ${ }^{1}$
}

\section{Examination of the Territorial Location and Clustering of the Hungarian Bank Branch Network in the Midst of the European Bank Branch Closure Trend in 2020}

\begin{abstract}
Az Európai Unió egészében a bankfiókok számának jelentös csökkenését tapasztaltuk az elmúlt években, amellyel összefüggésben felmerül a bankfiókok magyarországi területi rendelkezésre állásának kérdésköre. A tanulmány globális és lokális Moran's I statisztikákkal, valamint Getis-Ord féle $G^{*}$ hotspot elemzéssel a magyar bankfiókok elhelyezkedésének területi autokorrelációját és klasztereződését vizsgálja. Az eredmények alapján a bankfiókok száma Magyarországon települési szinten területileg pozitivan autokorrelált a 2020. januári állapot szerint. A települések bankfiókszámot tekintve klaszterekbe rendeződnek, ahol Budapest és vonzáskörzete egy jelentösebb csomópontnak számít, amelyhez hasonló az országban máshol nem található. Kiterjedtebb cold spotokat a Nyugat- és Dél-Dunántúl régió, valamint Észak-Magyarország és Szabolcs-Szatmár-Bereg megye országhatár menti térségeiben azonositottunk elsősorban.
\end{abstract}

JEL-kódok: G21, R12, R51

El-Meouch Nedim Márton a Pécsi Tudományegyetem Földtudományok Doktori Iskola doktori hallgatója. E-mail: nedu02@gmail.com

Alpek B. Levente a Pécsi Tudományegyetem Földrajzi és Földtudományi Intézet, Társadalomföldrajzi és Urbanisztikai Tanszék adjunktusa. E-mail: alpeklevente@gamma.ttk.pte.hu

Az Innovációs és Technológiai Minisztérium Kooperatív Doktori Program Doktori Hallgatói Ösztöndíj Programjának a Nemzeti Kutatási, Fejlesztési és Innovációs Alapból finanszírozott szakmai támogatásával készült. 
Kulcsszavak: bankfiókok, Magyarország, területi autokorreláció, klasztereződés, területi statisztika

In the European Union as a whole, we have seen a significant decrease in the number of bank branches in recent years, in connection with which the issue of spatial availability of bank branches in Hungary arises. The study examines the spatial autocorrelation and clustering of the location of Hungarian bank branches with global and local Moran's I statistics and Getis-Ord's Gi * hotspot analysis. Based on the results, the number of bank branches in Hungary is autocorrelated positively at the settlement level according to the situation in January 2020. In terms of the number of bank branches, the settlements are organized into clusters, where Budapest and its catchment area are a major junction, similar to which is not found elsewhere in the country. Extensive cold spots were primarily identified in the Western and Southern Transdanubia regions, as well as in the border areas of Northern Hungary and Szabolcs-Szatmár-Bereg County.

JEL codes: G21, R12, R51

Keywords: bank branches, Hungary, spatial autocorrelation, clustering, spatial statistics

\section{Bevezetés}

A kereskedelmi bankok működésük során fontos stratégiai célokat jelölnek ki, amelyek megvalósításához kapcsolódóan számos, a sikerességet, profitabilitást jelentősen befolyásoló rövid és hosszú távú döntést kell meghozniuk. Utóbbiak közül a bankfiókok elhelyezése az egyik meghatározó döntési pont, amely a fogyasztói bázis kialakításában, megtartásában is kiemelt szerepet játszhat, többek között a bankok egyik legalapvetőbb tevékenységét, a hitelezést tekintve is. A digitalizáció fokozódó térnyerése, amely a digitális bankolási szokásokra is nagy hatással van, valamint a 2008-as világgazdasági válság tanulságai csökkenő bankfiókszámot eredményeztek az európai bankrendszereket tekintve. Az Európai Központi Bank 2020-as adatai alapján 2008-2018 között az európai uniós bankfiókok 28\%-a ${ }^{3}$ bezárt, amely folyamatból Magyarország sem maradt ki, hazánkban szintén jelentős bankfiókbezárási trend volt tapasztalható az utóbbi években, a magyar 36\%-os bezárási arány a 12. legnagyobb érték európai uniós összehasonlításban. A 2008-as gazdasági válság legjelentősebb hatása a jelen kutatási témát tekintve, hogy a magyarországi bankoknál a fiókhálózat racionalizálása került előtérbe, a bezárásokkal elérhető költségcsökkentés kiemelt szerepet kapott a bankfióki stratégiákban. E folyamatot leginkább a magasnak tekinthető működési költségekkel és a digitalizáció térnyerésével együtt célszerű értelmezni. A racionalizálást elősegítette, hogy míg az eszközarányos működési költségek európai összehasonlításban

European Central Bank: Statistical Data Warehouse - SSI - Banking Structural Financial Indicators. 2020. A már nem EU-tagállam Egyesült Királyság bankfiókadatait nem számítva. A legutóbbi elérhető Egyesült Királyságra vonatkozó adattal is számolva, hasonló, 27\%-os bankfiókbezárási arány adódik. 
kiemelkedően magasnak számítanak a magyarországi bankok esetében, ${ }^{4}$ addig a digitalizáció által az internetbankolás egyre nagyobb népszerűségnek örvend az országban, a Központi Statisztikai Hivatal (KSH) 2018-as felmérése alapján a lakosság 76\%-a használ gyakran internetet, amely csoporton belül 54\% szokott online bankolni, ez utóbbi 7 százalékpontos évi növekedést jelez. ${ }^{5}$ Ezen tényezők mellett fontos megemlíteni, hogy a magyarországi bankfiókhálózat csökkenéséhez a 2014-ben kezdődő takarékszövetkezeti szektori integráció is nagyban hozzájárult, amelynek eredményeképpen a takarékszövetkezeti bankfiókjelenlét jelentősen mérséklődött, 2016 óta a takarékszövetkezeti szektor fiókjainak száma a felére csökkent. ${ }^{6} \mathrm{Az}$ integrációval bekövetkező, racionalizálási szempontokat követő fiókbezárások vidékre koncentrálódtak, a bezárások több mint kétharmada községek fiókjait érintette, amely települések így sok esetben bankfiók nélkül maradtak. ${ }^{7}$

A bankfiókbezárási trend több tekintetben a figyelem középpontjába helyezte a bankfiókokat, a bankfiókbezárási stratégiákat, valamint ezek területi vonatkozásait. Ezen kérdéskörön belül azon túl, hogy hazánk egyes térségei milyen mértékben ellátottak bankfiókokkal, felmerül annak a vizsgálatnak a szükségessége is, hogy ezen mintázat milyen térbeli jellegzetességet mutat, és amennyiben felfedezhetők összefüggések, azokban az egyes települések relatív pozíciója, helyzete a bankfiók-ellátottsági térképen milyen mértékben játszik szerepet. Jelentős e kérdéskör vizsgálata azért is, mert különösen a periférikus térségekben a bankfiókok rendelkezésre állása - összefüggésben többek között a mobilitás adott esetben alacsonyabb fokával ${ }^{8}$ - fontos szerepet játszhat a szolgáltatások rendelkezésre állásában. Ennek megfelelően jelen tanulmány azt vizsgálja, hogy a 2020. év eleji állapotot tekintve hogyan helyezkednek el a magyarországi bankfiókok, azok eloszlása területileg mennyire autokorrelált, kialakulnak-e különálló csoportok egyes térségekben bankfiókokkal való ellátottságot figyelembe véve. A kutatás egy új szempontból, a bankfiók-lefedettséget illetően ad egy képet a magyarországi települések helyzetéről, a különböző bankfiók „csomópontokról” és azok térbeli elhelyezkedéséről, valamint arról, hogy mely térségekben a leginkább jelentős a bankfiókok hiánya vagy az országos átlaghoz képest vett alacsonyabb aránya.

\section{Szakirodalmi áttekintés}

A fenti kérdéskört, vagyis a bankfiókok elhelyezkedését, elhelyezését számos munka tette vizsgálata tárgyává, amelyek köre kiterjedt a különböző döntés-előkészítő szoftverekhez kapcsolódó tanulmányokra, a bankfiókok elhelyezkedésében mintázatot kereső, azok hatótényezőit, a bankfióknyitásokat és -zárásokat vizsgáló tanulmányokra

Magyar Nemzeti Bank: Pénzügyi Stabilitási Jelentés (2019. május). Budapest, 2019.

Központi Statisztikai Hivatal: Digitális gazdaság és társadalom, 2018. Budapest, 2018.

Magyar Nemzeti Bank (MNB): P56-os „Pénzforgalmat bonyolító hálózati egységek és ATM-ek elhelyezkedésére, valamint a nyújtott szolgáltatásokra vonatkozó adatok” adatszolgáltatás, 2020.

MNB (2020) i. m.

Alpek B. Levente - Róbert Tésits - László Bokor: Group-specific analysis of commuting in the most disadvantaged areas of Hungary. Regional Statistics, 6. (2016), 1. 54-81.

Európai Tükör 2021/1. 
egyaránt. Előbbiek körén belül az egyik legkorábbi a David J. Willer tanulmányában ${ }^{9}$ kiindulópontként használt American Banking Association A Guide to Selecting Banking Locations kiadványa, ${ }^{10}$ amely egy a bankfiókok elhelyezéséről szóló döntési kalauz a kereskedelmi bankok számára. A kiadvány a fogyasztók szociogazdasági és demográfiai jellemzői (bankfiók környékén élő és dolgozó népesség aránya), a helyi verseny mértéke (megszerezhető piaci részesedés becslése) és a fogyasztási szokások alapján nyújtott segítséget a bankfiók elhelyezéséről való döntésben. A kalauz 1970-es évek előtti megléte érzékelteti, hogy a bankfiókokról való döntés fontos feladat egy bank életében, amely jelentős mértékű megelőző elemzést, kutatást igényel. Anton C. M. Hopmans ${ }^{11}$ a Rabobank rendszeréről írt cikket, amelyet a bank arra használt, hogy a segítségével kialakítsa bankhálózatát. Ugyanakkor ennek a rendszernek nem a települések közüli választás volt a célja, hanem a helyi lokációról való döntés. A bankfiókok klasztereződését a különböző kalauzok, szoftverek használata már önmagában elősegítheti, abban az esetben, ha a kereskedelmi bankok hasonló alapokon nyugvó útmutatók, illetve szoftverek alapján választják ki a bankfiókjaik helyszíneit. Ekkor a bankok az optimális elhelyezésre irányuló keresés során, tekintettel a társadalmi-gazdasági és környezeti faktorok jellegzetes mintázatára hasonló döntésekre juthatnak, amely klaszterezett bankfiók-elhelyezkedéshez vezethet. Ez természetesen jelentős mértékben függhet az adott szoftver paraméterezésétől, sajátosságaitól és a döntéshez kapcsolódó egyéb elemektől is.

A bankfiókokról értekező, viselkedési mintázatokat kereső cikkek között jelennek meg többek között azok a tanulmányok, amelyek a bankfiókok klasztereződését kutatják. Angela Chang és szerzőtársai ${ }^{12}$ kutatásuk során azt vizsgálták, hogy a klasztereződés magyarázható-e teljes mértékben az adott lokációkra vonatkozó olyan jellemzőkkel (demográfiai, gazdasági változók), amelyek meghatározzák a banki szolgáltatásokkal szembeni keresletet. Amennyiben ez így van, úgy a bankfiókok elhelyezkedése csak ezen piaci szempontokat követi. Arra jutottak, hogy e jellemzők nem magyarázzák meg teljes mértékben a bankfiókok elhelyezkedését, a kimaradó részt egy „rational herding” nevü jelenséghez kötik, amely szerint még akkor is lehet racionális más szereplők viselkedésének lemásolása, ha az szuboptimális eredményre vezet. E jelenség mögött álláspontjuk szerint az állhat, hogy vagy dominálják a már múködő bankfiókoktól származó információk az egyéb információkat, vagy az adott menedzserek saját pozíciójukat védik a kevésbé kockázatos, más bankoknak már bevált lokáció kiválasztásával. Ez gyakorlatban azt jelenti, hogy a bankok hajlamosak még akkor is ugyanott nyitni bankfiókot, mint a versenytársak, ha ezt az adott lokáció jellemzői nem magyarázzák meg teljes mértékben, amely jelenség szintén térbeli klasztereződéshez vezethet. ${ }^{13} \mathrm{~A}$ klasztereződés másik

David J. Willer: A Spatial Decision Support System for Bank Location: A Case Study. Technical Report 90-9, 1990.

10 American Bankers Association: A Guide to Selecting Bank Locations. A.B.A. Marketing Research Aids Series Number 2. New York, American Bankers Association, 1968.

11 Anton C. M. Hopmans: A spatial interaction model for branch bank accounts. European Journal of Operational Research, 27. (1986), 2. 242-250.

12 Angela Chang - Shubham Chaudhuri - Jith Jayaratne: Rational herding and the spatial clustering of bank branches: An empirical analysis. Columbia University Department of Economics Discussion Papers, 9697-24. (1997), 1-34.

13 Chang-Chaudhuri-Jayaratneet (1997) i. m. 
magyarázata jelenik meg Shusen Qi és szerzőtársainak ${ }^{14}$ tanulmányában, amelyben a szerzők arra mutatnak rá, hogy annak mértéke aszerint növekszik, ahogy a bankok közötti információmegosztás megjelenik, vagy minősége emelkedik. Eredményeik szerint a hitelinformációs rendszer megjelenésének vagy fejlesztésének hatására a bankok számukra még ismeretlen, de más bank által már lefedett lokációkon telepítenek bankfiókot. Tehát arra jutnak, hogy a bankfiókok klasztereződésének mértéke növekszik az információmegosztás szintjének növekedésével, mert bár egy-egy bank olyan lokációkon nyit fiókot, ahol adott esetben korábban nem volt jelen, de ezek dominánsan olyan helyszínek, amelyeken más bankok már korábban megjelentek. A banki, bankfióki terjeszkedést befolyásolja továbbá az azonos országból származó termelővállalatok külföldre való terjeszkedésének lekövetése, amely „follow-the-customer" hipotézisként terjedt el a szakirodalomban. ${ }^{15}$ Ezen elmélet párjaként egy másik, a „lead-the-customer” hipotézis is megjelent, amely szerint a bankok nemcsak lekövetik ügyfeleiket, hanem képesek őket külföldre is csábítani. ${ }^{16}$ Előbbi mögött az áll, hogy a külföldre terjeszkedő vállalatok szívesebben létesítenek üzleti kapcsolatot a saját országukból származó, már ismert és hasonló kultúrájú kereskedelmi bankokkal, amely a terjeszkedni kívánó kereskedelmi banknak is nagy versenyelőnyt jelent a helyi bankokkal szemben, míg az utóbbi azzal magyarázható, hogy a külföldön jelen lévő bankok addicionális információval, kapcsolatokkal és tanácsokkal tudják ellátni a külföldi megjelenést tervező vállalatokat. Charles Okeahalam, ${ }^{17}$ illetve David Ansong és szerzőtársai ${ }^{18}$ vizsgálatukat empirikus bázisra helyezve kitérnek a bankfiókok klasztereződésének kérdéskörére is. Előbbi tanulmány Dél-Afrika példáján keresztül közelíti a területet, és bár alapvető célja a bankfiókok elhelyezkedését magyarázó változók megtalálása, eredményeiben a más változók által nem magyarázott klasztereződésre hívja fel a figyelmet. Utóbbi kutatás Kenya esetét járja körül a bankfiókok elhelyezkedésére vonatkozóan. A tanulmány során többször is kiemelik a bankfiók-lefedettségbeli különbségeket az északi, vidéki jellegű és a déli, városias országrész között. A cikk a bankfiókok eloszlásának sűrűségében tapasztalható eltérést elsősorban az urbanizációs szintben tapasztalható különbségekhez köti.

\footnotetext{
$14 \quad$ Shusen Qi et alii: Move a little closer? Information sharing and the spatial clustering of bank branches. EBRD Working Paper, (2018), 223. 1-55.

15 Herbert Grubel: A theory of multinational banking. PSL Quarterly Review, 30. (1977), 123. 349-363.; Joydeep Bhattacharya: The role of foreign banks in developing countries: a survey of the evidence. Working Paper. Ames, Iowa, 1994.; José P. Esperanca - Mohamed A. Gulamhussen: (Re)Testing the 'follow the customer' hypothesis in multinational bank expansion. Journal of Multinational Financial Management, 11. (2001), 3. 281-293.

16 Ingo F. Walter: Global Competition in Financial Services: Market Structure, Protection, and Trade Liberalization. Cambridge, MA, Ballinger, 1988.; Bhattacharya (1994) i. m.

17 Charles Okeahalam: Bank branch location: a count analysis. Spatial Economic Analysis, 4. (2009), 3. 275-300.

18 David Ansong - Gina Chowa - Bernice Korkor Adjabeng: Spatial analysis of the distribution and determinants of bank branch presence in Ghana. International Journal of Bank Marketing, 33. (2015), 3. 201-222.
} 
A magyar bankfiókok területi elhelyezkedését illetően Gál Zoltán cikke ${ }^{19}$ az 1990 -es évek elejétől indul, és a bankrendszer strukturális fejlődését vizsgálja. Kiemeli, hogy a magyar bankrendszer centralizált struktúrában múködött a rendszerváltás idején, területileg pedig kiegyensúlyozatlan és koncentrált volt. A kiegyensúlyozatlanság okaként hozza fel, hogy a rendszerváltás előtt az iparosítás volt a fő mozgatórugója a magyarországi gazdaságfejlesztési logikának, így a nyugati megyék elhanyagoltak maradtak a keleti megyékhez képest. Ez az egyenlőtlenség a rendszerváltás után kissé enyhült, a bankok a nyugati országrészben is nagyobb arányba jelentek meg bankfiókokkal. A magyarországi bankfiókhálózattal foglalkozik Kovács Sándor Zsolt tanulmánya ${ }^{20}$ is, amely a város-vidék különbözőségeket vizsgálja a különböző településhierarchia-szinteken, kiemelt figyelmet fordítva a kereskedelmi bankok és szövetkezeti hitelintézetek különbözőségeire. Eredményei alapján a magasabb településhierarchia-szinteken a kereskedelmi bankok fiókjainak, míg az alacsonyabb hierarchiai szinteken a takarékszövetkezeti intézmények fiókjainak túlsúlya tapasztalható, amely alapvető múködési sajátosságaikból fakad. Emellett a cikkben megvilágításra kerül, hogy a megelőző évek fiókbezárásai tovább erősítik a - az alapfolyamatoknak köszönhetően egyébként is kialakuló - pénzügyi szolgáltatások koncentrálódását a járási centrumokba, amely így a bankfiókok eléréséhez szükséges időt növelheti. Temesvary Judit munkája ${ }^{21}$ arra hívja fel a figyelmet, hogy a magyarországi banki versenynek a fiókhálózat is fontos tényezője, és a versenytársak bankfióknyitása növeli a saját bankfióknyitás valószínűségét egy adott banknál. Ami a szomszédos országok bankfiókhálózatának területi aspektusaival foglalkozó szakirodalmi munkákat illeti, Johann Burgstaller ${ }^{22}$ az ausztriai bankfiókbezárásoknak, míg Bod’a és Čunderlíková ${ }^{23}$ a szlovákiai bankfióksűrüség elhelyezkedésének befolyásoló tényezőit vizsgálták. Burgstaller ${ }^{24}$ arra jut az 1999-2012 közötti bankfiókbezárások alapján, hogy a kevésbé fejlett és a funkcionálisan távoli településeken zárnak be legnagyobb mértékben a bankfiókok, amelyek így pénzügyileg elsivatagosodhatnak. Mivel a funkcionálisan távoli bankfiókok a centrumtól távol eső településeken zárnak be, így ezen folyamat a bankfiókok területi koncentráltságát növelheti. Bod’a és Čunderlíková ${ }^{25}$ kutatása 2016-os adatokon azt mutatja meg, hogy a bankfiókhálózat sűrűségét társadalmi, demográfiai és gazdasági tényezők befolyásolják, amelyek közül a helyi lakosság átlagos keresete, mérete, átlagos életkora, az egyetemi végzettségúek aránya és a bankfiók-koncentráció a leginkább meghatározók.

19 Gál Zoltán: The development and the polarised spatial structure of the Hungarian banking system in a transforming economy. In Barta Györgyi - Fekete G. Éva - Szörényiné Kukorelli Irén - Timár Judit (eds.) Hungarian Spaces and Places: Patterns of Transition. Chapter 12. Pécs, Centre for Regional Studies of the Hungarian Academy of Sciences, 2005. 197-219.

20 Kovács Sándor Zsolt: Város-vidék-kapcsolat a magyar pénzintézethálózatban. Területi Statisztika, 57. (2017), 5. 495-511.

21 Judit Temesvary: Some determinants of commercial bank behavior. Doctoral Dissertation, Faculty of the Graduate School of Cornell University, Degree of Doctor of Philosophy, 2011.

22 Johann Burgstaller: Dynamics of Retail-Bank Branching in Austria. Economic Notes, 46. (2017), 3. 527-554.

${ }^{23}$ Martin Bod’a - Katarína Čunderlíková: Determinants of bank branch density: A case study of Slovakia. International Journal of Bank Marketing, 38. (2020), 4. 933-959.

24 Burgstaller (2017) i. m.

25 Bod’a-Čunderlíková (2020) i. m. 
E tanulmányok mind felhívják a figyelmet a bankfiókok elhelyezkedésének területileg klasztereződő természetére, emellett azt taglalják, hogy ennek milyen okai lehetnek. Jelen tanulmány a magyar bankrendszert elemzi területi autokorrelációs szempontból, célja a klasztereződés vizsgálata és e koncentrációk területi eloszlásának feltérképezése.

\section{Kutatási módszerek}

Az elemzéshez használt bankfiókadatok a Magyar Nemzeti Bank P56-os, „Pénzforgalmat bonyolító hálózati egységek és ATM-ek elhelyezkedésére, valamint a nyújtott szolgáltatásokra vonatkozó adatok" elnevezésű adatszolgáltatásának köszönhetően álltak rendelkezésre. Az adatszolgáltatás során a magyarországi hitelintézeteknek és takarékszövetkezeteknek részletes adatokkal kell szolgálniuk a bankfiókjaikat és azok jellemzőit tekintve. Az adatszolgáltatásnak köszönhetően a magyarországi fiókhálózat területi elhelyezkedését 2020. január 31-re vonatkozóan tártuk fel.

A kutatásban a térszerkezet leíró statisztikai módszereken keresztül történő bemutatásán túl területi statisztikai módszertan segítségével vizsgáljuk meg, hogy a bankfiókok térben hogyan helyezkednek el Magyarországon. Az elemzés a klasztereződést, a területi autokorreláció meglétét vizsgálja, területi kerete a magyarországi települések köre. Területi autokorrelációról beszélhetünk abban az esetben, ha egy ismérv területi eloszlása összefügg az elemzésben részt vevő megfigyelések közötti távolsággal. Egyik példája a pozitív területi autokorreláció, amely esetén a területi különbségekre a szomszédsági viszonyok jelentősen hatnak, az egymáshoz közelebb lévő megfigyelések jobban hasonlítanak egymásra. ${ }^{26} \mathrm{~A}$ jelen kutatás a bankfiókok számának területi autokorrelációját elsőként globális Moran’s I, majd lokális Moran’s I statisztikákkal vizsgálja, amely elemzések az lctools R szoftverhez telepíthető csomag segítségével készültek el. ${ }^{27}$ Klasszikus teszt a területi autokorreláció meglétének vizsgálatára a globális Moran's I statisztika, amely a teljes adathalmaz vonatkozásában számítja ki a területi autokorreláció meglétét. A statisztikát az alábbi egyenlet által számítjuk ki: ${ }^{28}$

$$
I=\frac{n}{2 A} *\left(\frac{\delta_{i j} * \sum_{i=1}^{n} \sum_{j=1}^{n}\left(y_{i}-\bar{y}\right) *\left(y_{j}-\bar{y}\right)}{\sum_{i=1}^{n}\left(y_{i}-\bar{y}\right)^{2}}\right)
$$

ahol $n$ a megfigyelések száma, $y_{i}$ a vizsgálat középpontjában lévő változó $i$ megfigyeléshez tartozó értéke, $\bar{y}$ a vizsgált változó súlyozatlan átlaga, $A$ a szomszédsági kapcsolatok száma, $\delta_{i, j}$ értéke pedig 1 , ha $i$ és $j$ szomszédosak, egyébként pedig 0. A globális Moran's I értéke -1 és 1 közötti sávba eshet, pozitív területi autokorreláció esetén a statisztika szignifikánsan pozitív (és 1-hez közelítve egyre erősebb), negatív területi autokorreláció esetén szignifikánsan negatív értéket vesz fel (és -1-hez közelítve egyre erősebb). 0 közeli értékek a területi autokorreláció hiányára utalnak.

\footnotetext{
26 Tóth Géza - Kincses Áron: A mai magyarországi bevándorlás térbeli autokorreláltsága. Földrajzi Közlemények, 135. (2011), 1. 83-91.

27 www.rdocumentation.org/packages/lctools/versions/0.2-8.

28 Patrick A. P. Moran: The interpretation of statistical maps. Journal of the Royal Statistical Society. Series B, 10. (1948), 2. 243-251.
}

Európai Tükör 2021/1. 
A lokális Moran's I statisztika a globálishoz hasonlóan a területi autokorrelációt méri, de nem a teljes adathalmazon, hanem lokálisan, egy adott megfigyelés szempontjából teszi azt. Tehát a statisztika az adott megfigyelés körüli szomszédság értékeivel hasonlítja össze a ponthoz tartozó értéket, és az adott pontra vonatkozóan ad képet a területi autokorrelációról. ${ }^{29}$ Ezenfelül a lokális Moran's I azt is megmutatja, hogy a teljes adathalmazt jellemző területi autokorreláció mekkora része köszönhető az adott megfigyeléseknek, mi az adott megfigyelés hozzájárulása a teljes egészhez. ${ }^{30} \mathrm{~A}$ lokális Moran's I statisztikát a következő képlet alapján számítjuk ki: ${ }^{31}$

$$
I_{i}=\frac{Z_{i}-\bar{Z}}{S_{Z}^{2}} * \sum_{j=1}^{N}\left[W_{i j} *\left(Z_{j}-\bar{Z}\right)\right](2)
$$

ahol $\bar{Z}$ a megfigyelések átlaga, $Z_{i}$ az $i$ megfigyelés értéke, $Z_{j}$ a további megfigyelések értékei, $S_{Z}^{2}$ a vizsgált egységekhez tartozó változóértékek szórása, $W_{i j}$ pedig a szomszédsági mátrix adott értékeihez tartozó súly. A statisztika értékei a globális Moran's I-hez hasonlóan értelmezendők. A lokális Moran's I statisztika alapján az elemzés öt csoportba osztja a településeket a területi autokorreláció és a bankfiókok számossága alapján. Az öt csoport a következőképpen alakul ki: 0. csoport - autokorreláció nélküliek (nem szignifikánsan autokorrelálók); 1. csoport: pozitívan autokorrelálók, magas lokális és környékbeli bankfiókszámmal; 2. csoport: pozitívan autokorrelálók, alacsony lokális és környékbeli bankfiókszámmal; 3. csoport: negatívan autokorrelálók, alacsony lokális és magas környékbeli bankfiókszámmal; 4. csoport: negatívan autokorrelálók, magas lokális és alacsony környékbeli bankfiókszámmal.

Jól látható, hogy a globális és a lokális Moran’s I területi autokorrelációs számításhoz elkerülhetetlen a szomszédság definiálása. Ez alapvetően kétféleképpen végezhető el: 1. a számítás lefuttatásához bemenő paraméterként meg kell adni egy előre összeállított szomszédsági mátrixot, és azzal készülnek el a számítások; 2. a megfigyeléseket a tér egy pontjához kötjük, és a szomszédságot a szomszédos területek, zónák segítségével vagy a megfigyelések közötti távolsággal határozzuk meg, utóbbinál a távolabb lévő megfigyeléseket akár kisebb súllyal figyelembe véve. ${ }^{32}$ Globális és lokális Moran’s I statisztikákat is kiszámítunk jelen elemzésben, amelyeknek szomszédságdefiníciójában felhasználjuk a települések elhelyezkedését is. Az elemzésben végzett Moran’s I számításoknál a bemenő szomszéd szám paraméter ( $n$ ) azt hivatott jelezni, hogy a térbeli távolságot tekintve legközelebb eső $n$ megfigyelés van szomszédként definiálva. E paraméter kiválasztásával számítjuk ki a lokális és globális területi autokorreláció meglétét mutató statisztika értékét.

A bankfiókszámok tekintetében magyarországi hotspotok és cold spotok vizsgálatára is sor került, amelyhez a lokális G-t használtuk fel, amely statisztikát az Arthur

\footnotetext{
29 Tóth Géza: Területi autokorrelációs vizsgálat a Local Moran I módszerével. Tér és Társadalom, 17. (2003), 4. 39-49.

30 Luc Anselin: Local Indicators of Spatial Association_LISA. Geographical Analysis, 27. (1995), 2. 93-115.

31 Arthur Getis - Keith J. Ord: Local spatial statistics: an overview. In Longley, Paul-Batty, Michael (eds.): Spatial Analysis: Modelling in a GIS Environment. John Wiley \& Sons, 1996. 261-277.

32 Tóth (2003) i. m.
} 
Getis - J. Keith Ord $^{33}$ és Ord-Getis ${ }^{34}$ tanulmányokban fejtettek ki. A módszer területi mintázatokat keres, azt mutatja meg, hogy egyes térbeli pontok, megfigyelések környezetében a teljes adathalmazhoz képest szignifikánsan magasabb (sűrúbb) vagy alacsonyabb (ritkább) intenzitással fordul-e elő a vizsgált változó, amennyiben igen, akkor az hotspotnak vagy cold spotnak tekinthető. ${ }^{35}$ A Getis-Ord-féle lokális G-nek két változata van, az egyik a vizsgált pont környékét vizsgálja, a vizsgált pont figyelembevétele nélkül (lokális $G$ ), a másik a vizsgált pontot is figyelembe veszi, az odatartozó változó értéket is beszámítja (lokális $\mathrm{G}^{*}$ ). Jelen kutatás az utóbbit használja, amelynek képlete a következő: ${ }^{36}$

$$
G_{i}^{*}=\frac{\sum_{j=1}^{M} w_{i j} d_{j}}{\sqrt{\frac{\sum_{j=1}^{M} d_{j}^{2}}{M}} \sqrt{\frac{M \sum_{j=1}^{M} w_{i j}^{2}-\left(\sum_{j=1}^{M} w_{i j}\right)^{2}}{M-1}}}
$$

ahol $M$ a vizsgált megfigyelések száma, $w_{i j}$ a szomszédsági mátrix $i$-edik sorának $j$-edik eleme, pedig a megfigyelés adott változóhoz tartozó értékének az átlagtól vett eltérése. A statisztika standard normális eloszlást követ, így ennek megfelelően kell értelmezni azt, hogy a konkrét érték adott szignifikanciaszinten jelentősen eltér-e pozitívan vagy negatívan az átlagostól. 5\%-os szignifikanciaszinten pozitívan szignifikáns statisztikáról beszélhetünk 1,96-ot meghaladó értékeknél, negatívan szignifikánsról a -1,96-nál alacsonyabb értékeknél. A Getis-Ord-féle lokális G* hotspot elemzést a GeoDa nevú Luc Anselin és szerzőtársai ${ }^{37}$ által kifejlesztett szoftver segítségével végeztük el. Az elemzett eredmény esetében bemenő paraméterként az öt legközelebbi szomszéd, szomszédmátrix-súlyozásnál pedig sorstandardizált beállítás lett kiválasztva. ${ }^{38}$

\section{Eredmények}

A Magyarországon lévő 3177 településből 2456 település nem rendelkezett a vizsgálat időpontjában bankfiókkal, amelyek közül csak kilenc település volt város, a többi mind községet takart. A többi, bankfiókkal rendelkező 721 magyar településen 2020 január végén 1913 bankfiók helyezkedett el. A bankfiókok 43\%-a városokban, 18\%-a fővárosi kerületekben, 19\%-a községekben, 20\%-a pedig megyei jogú városokban volt található. A települések bankfiókszámának településtípus szerint bontott leíró statisztikái

33 Arthur Getis - Keith J. Ord: The analysis of spatial association by use of distance statistics. Geographical Analysis, 24. (1992), 3. 189-206.

34 Keith J. Ord - Arthur Getis: Local spatial autocorrelation statistics: distributional issues and an application. Geographical Analysis, 27. (1995), 4. 286-306.

35 Szakálné Kanó Izabella: A gazdasági aktivitás térbeli eloszlásának vizsgálati lehetőségei. Statisztikai Szemle, 89. (2011), 1. 77-100.

$36 \quad$ Szakálné Kanó (2011) i. m.

37 Luc Anselin - Ibnu Syabri - Youngihn Kho: GeoDa: An introduction to spatial data analysis. Geographical Analysis, 38. (2006), 1. 5-22.

38 A lokális G* elemzés esetében is meg lett vizsgálva az eredmény egyéb bemenő paraméterek (más szomszéd szám vagy bináris súlyozás) megadásával is. Ezek bár a hot- és cold spotok méretét néhol megváltoztatták, lényegi változást nem eredményeznek a fő következtetéseket tekintve.

Európai Tükör 2021/1. 
az 1. táblázatban láthatók, amelyből kitűnik, hogy a megyei jogú városokban/megyeszékhelyeken és a fővárosi kerületekben az átlagos bankfiókszám jóval meghaladja a többi városra, valamint a községekre adódó átlagos bankfiókszámot.

1. táblázat

A bankfiókszámok településtípus szerint bontott leíró statisztikái (2020)

\begin{tabular}{|c|r|r|c|}
\hline Településtípus & Átlag & Szórás & Relatív szórás \\
\hline Község & 0,13 & 0,35 & 264,36 \\
\hline Város & 2,53 & 1,89 & 74,56 \\
\hline Megyei jogú város/megyeszékhely & 16,65 & 6,00 & 36,06 \\
\hline Fővárosi kerület & 14,87 & 7,92 & 53,24 \\
\hline
\end{tabular}

Forrás: MNB alapján a szerzők számítása

A magyar bankfiókokelhelyezkedését és számosságát települési szinten az1.ábra mutatja. A Gál 2005-ös cikkében ${ }^{39}$ megemlített keleti-nyugati egyensúlytalanság 2020-ban is megfigyelhető, a keleti megyékben a települések 33\%-a rendelkezett bankfiókkal, míg a nyugati megyékben ez csak a települések 14\%-ára volt igaz. Az ábrán is látszik, hogy a megyeszékhelyeken és - kisebb mértékben - azok körül található a bankfiókok nagy része, míg a megyeszékhelyektől távoli kisebb községekben csak elvétve találni azokat. Különösen igaz ez a nyugati országrész tekintetében. Leginkább a délnyugati és az északkeleti régió aprófalvas térségei esetében látható, hogy a legközelebbi bankfiók is jó pár településsel arrébb helyezkedik el.

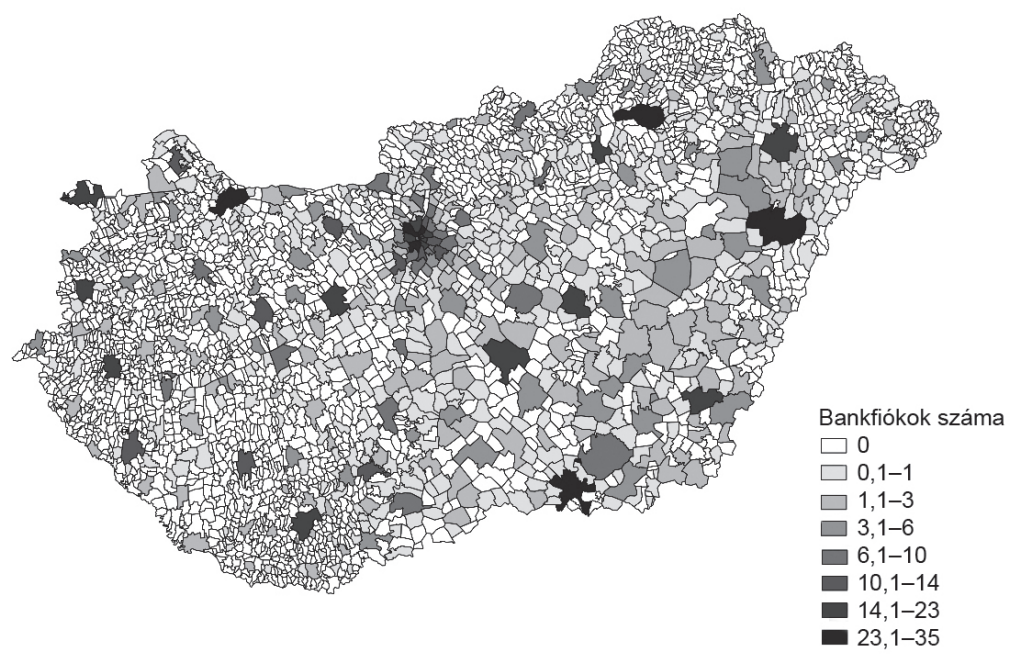

1. ábra

Bankfiókok száma a magyarországi településeken (2020)

Forrás: MNB alapján a szerzők szerkesztése

39 Gál (2005) i. m. 
Ahogy az a módszertanban is kiemelt figyelmet kapott, fontos a Moran's I statisztikák esetében a szomszédság definiálása, azok számának meghatározása. Annak érdekében, hogy az eredményeket ne a szomszéd szám beállítása vigye el valamely irányba, a globális Moran's I statisztikákat 1-25 között az összes szomszéd szám bemenő paraméterrel megvizsgáltuk. Emellett az eredmények szomszédmátrix-súlyozásra való érzékenységét is ellenőriztük, az elemzés mind a bináris értékeket tartalmazó (0 vagy 1), mind a távolság alapján súlyozott szomszéd mátrix használatával elkészült. Az így kapott globális Moran’s I statisztikák értékei a 2. ábrán láthatók. Az eredmények azt mutatják, hogy a magyarországi bankfiókok elhelyezkedését tekintve jelentős területi autokorreláció figyelhető meg szomszédszám-beállítástól és szomszédmátrix-súlyozástól függetlenül, az összes vizsgált szomszéd szám és súlyozás bemenő paraméter beállítása mellett. A binárisan és a távolság alapján súlyozott statisztikák között lényegi különbség nem figyelhető meg, annyiban térnek el egymástól, hogy a súlyozott statisztika értéke stabilabban alakul a szomszéd szám változásával, míg a bináris súlymátrixos statisztikák értéke enyhén csökken a szomszéd szám emelkedésével. A bináris súlymátrixú globális Moran's I statisztikák 0,261-0,305 közötti, a távolság szerint súlyozott súlymátrixúak 0,291-0,301 közötti értékeket vesznek fel az egyes futások esetében, amelyek a területi autokorrelációt nélkülöző, várt -0,0003-as globális Moran's I értéktől minden szomszédszám-érték esetén szignifikánsan eltérnek. ${ }^{40}$ Tehát a bankfiókok száma települési szinten mérve területileg pozitívan autokorrelál, ami azt jelenti, hogy a teljes adathalmazt tekintve területi klaszterezettség van jelen, a relatíve sok bankfiókkal rendelkező települések környékén várhatóan relatíve sok bankfiókkal rendelkező település fekszik, a relatíve kevés bankfiókos települések környékén pedig relatív kevéssel rendelkezők.

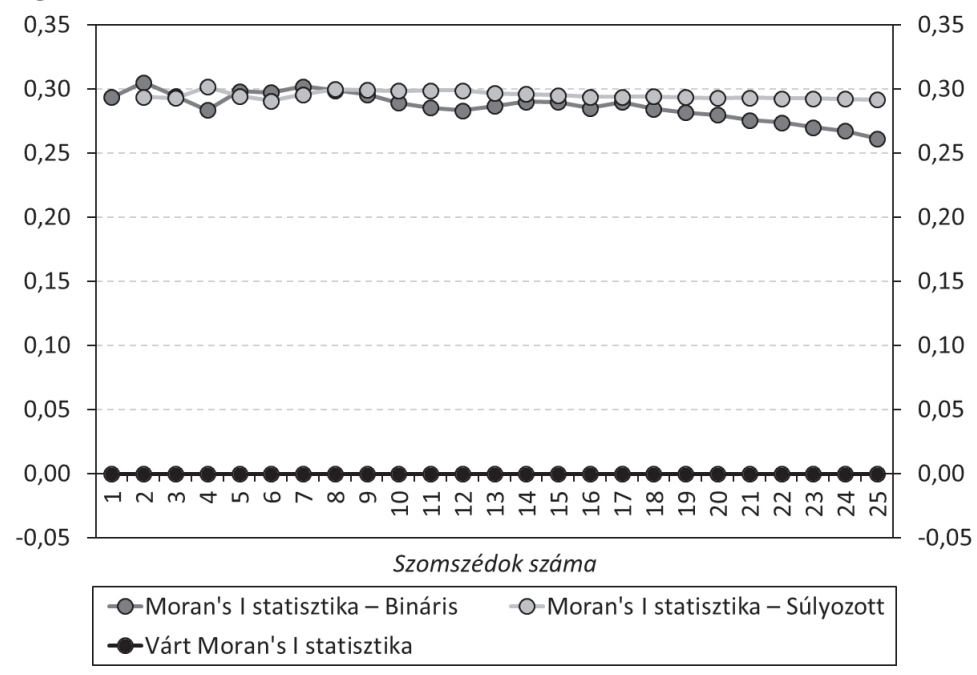

2. ábra

A bankfiókok elhelyezkedésére futtatott globális Moran's I tesztstatisztikák alakulása a kiválasztott szomszédszám- és szomszédmátrix-súlyozás függvényében (2020)

Forrás: MNB alapján a szerzők számítása

40 Az e statisztikákhoz tartozó $p$ értékek nullához közelik. 
Az egyes megfigyelések szempontjából vett területi autokorrelációnak, valamint az e megfigyelések teljes területi autokorrelációhoz való hozzájárulásának elemzése érdekében, lokális Moran’s I statisztika segítségével készültek további vizsgálatok. A használt eljárás a lokális Moran's I statisztikák kiszámítása mellett, csoportokba helyezi az egyes megfigyeléseket a bankfiókváltozójuk standardizált értéke, a késleltetettjük standardizált értéke (amely a szomszédos megfigyelések súlyozott bankfiók értékeinek standardizáltját jelenti), valamint a lokális Moran's I statisztikájuk szignifikanciája alapján. ${ }^{41}$ E jellemzők alapján a magyarországi településeket a szoftver öt csoportra osztotta, amelyből egybe, a második csoportba nem került egy megfigyelés sem, így ténylegesen összesen négy csoportot képzett. ${ }^{42} \mathrm{~A}$ statisztika futtatásánál bemenő paraméterként öt szomszéd és bináris súlymátrix lett megadva. ${ }^{43} \mathrm{~A}$ négy csoport és az azokra jellemző adatok a 2. táblázatban láthatók, térbeli ábrázolásukat pedig a 3. ábra tartalmazza. $\mathrm{Az}$ öt (ténylegesen négy) csoport az adatok és a térkép segítségével jól elkülöníthető egymástól, a nulladik csoportba az autokorreláció nélküliek (nem szignifikánsan autokorrelálók), az első és második csoportba a pozitívan autokorrelálók (magas-magas, alacsony-alacsony), a harmadikba és negyedikbe pedig a negatívan autokorrelálók kerültek (alacsony-magas, magas-alacsony). ${ }^{44} \mathrm{~A}$ nulladik csoportba olyan, jellemzően vidéki községek és kisvárosok kerültek, amelyekben az átlagostól alig eltérő számú bankfiók található, emellett a környező településeken is hasonló a helyzet, ezeknél a területi autokorreláció nem erős. Az első csoportba jellemzően a budapesti kerületek és a Budapest környéki Pest megyei városok kerültek, ezeket egy Hajdú-Bihar megyei (Hajdúböszörmény), egy Bács-Kiskun megyével határos Pest megyei (Nagykőrös) és egy Baranya megyei (Kozármisleny) település egészíti ki. E csoportra elmondható, hogy az átlagnál több bankfiók található az idetartozó településeken és a környező településeken is, ennek megfelelően nagyon erős pozitív korrelációt mutat esetükben a lokális Moran's I. A teljes adathalmazra jellemző szignifikánsan pozitív területi autokorreláció szinte teljes egészében ennek a csoportnak köszönhető. A harmadik csoportba csak egy, Budapesttel Észak-Nyugatról határos outlier település (Remeteszőlős) került, amely alacsonyabb bankfiókszáma mellé sok bankfiókos szomszédokkal rendelkezik. A negyedik csoportba pedig, mint ahogy az ábrán is látható, 14 megyeszékhely és nagyváros került, amelyekben az átlagos bankfiókszám magas, viszont a környező településeken nagyon

$41 \quad$ Az eljárás Anselin és szerzőtársai 2006-os cikke alapján, a szerzők által működtetett GeoDa szoftverben leírt eljáráshoz hasonló módszerrel helyezi csoportokba a megfigyeléseket.

42 A csoportok a területi autokorreláció és a bankfiókok számossága alapján lettek csoportosítva. A második csoportba azért nem került megfigyelés, mert oda a nagyon alacsony (átlagostól jóval alacsonyabb) bankfiókszámmal és nagyon alacsony bankfiókszámú szomszédos településekkel rendelkező (alacsony-alacsony) települések kerültek volna be (amelyek így pozitívan lettek volna autokorreláltak). Amint látható, ilyen összefüggést nem talált a lokális Moran's I számítás, amelynek magyarázata lehet, hogy negatívan nem volt lehetséges jelentősen eltérni az átlagos bankfiókszámtól, amely a 3173 településre nézve 0,6 volt.

43 A számítások különböző szomszédszám- és szomszédmátrix-súlyozás paraméterekkel is le lettek futtatva, amelyekből kiderült, hogy e paraméterekre nézve az eredmények robusztusak, nem változnak érdemben.

44 Zárójelben az adott településen lévő bankfiókok relatív mennyisége és a szomszédos településeken lévő bankfiókok relatív mennyisége szerepel. Ezek alapján látható, hogy a pozitívan (1-2) és a negatívan autokorreláló (3-4) csoportokat az adott településen és a környéken (szomszédos településen) lévő bankfiókok átlagos száma különíti el egymástól. 
alacsony, ezeknél negatív autokorreláció tapasztalható. Jól megfigyelhető, hogy míg Budapestet egy bankosodott, annak kerületeivel pozitívan autokorreláló agglomeráció veszi körül, addig az ország többi megyeszékhelyét tekintve vagy nem tapasztalható jelentős autokorreláció a megyeszékhely körül, vagy kifejezetten negatív az autokorreláció a környező településeket tekintve. Ez azt mutatja, hogy míg Budapest esetén egy bankfiókokkal jól lefedett agglomeráció alakult ki a környező településeken, amely a gazdasági fejlődést elősegítheti a térségben, addig a többi megyeszékhelyen ez nem vagy csak mérsékelten valósult meg a bankfiókok tekintetében.

\section{2. táblázat}

A lokális Moran’s I számítások által kijelölt csoportok és az azokra jellemző értékek (2020)

\begin{tabular}{|c|c|c|c|c|}
\hline Csoport & $\begin{array}{c}\text { Települések } \\
\text { száma }\end{array}$ & Lokális Moran's & $\begin{array}{c}\text { Standardizált } \\
\text { bankfiók érték } \\
\text { átlaga a településen }\end{array}$ & $\begin{array}{c}\text { Standardizált } \\
\text { bankfiók érték } \\
\text { átlaga a szomszéd } \\
\text { településeken }\end{array}$ \\
\hline 0 & 3121 & 0,02 & $-0,09$ & $-0,08$ \\
\hline 1 & 37 & 24,29 & 4,72 & 6,83 \\
\hline 3 & 1 & $-1,24$ & $-0,27$ & 7,22 \\
\hline 4 & 14 & $-1,46$ & 7,79 & $-0,27$ \\
\hline Összesen & 3173 & 0,2982 & 0,0000 & 0,0000 \\
\hline
\end{tabular}

Megjegyzés: A negyedik és ötödik oszlopban a bankfiókok számára vonatkozó átlagok a standardizálásból következően vehettek fel negatív értéket. Forrás: MNB alapján a szerzők számítása

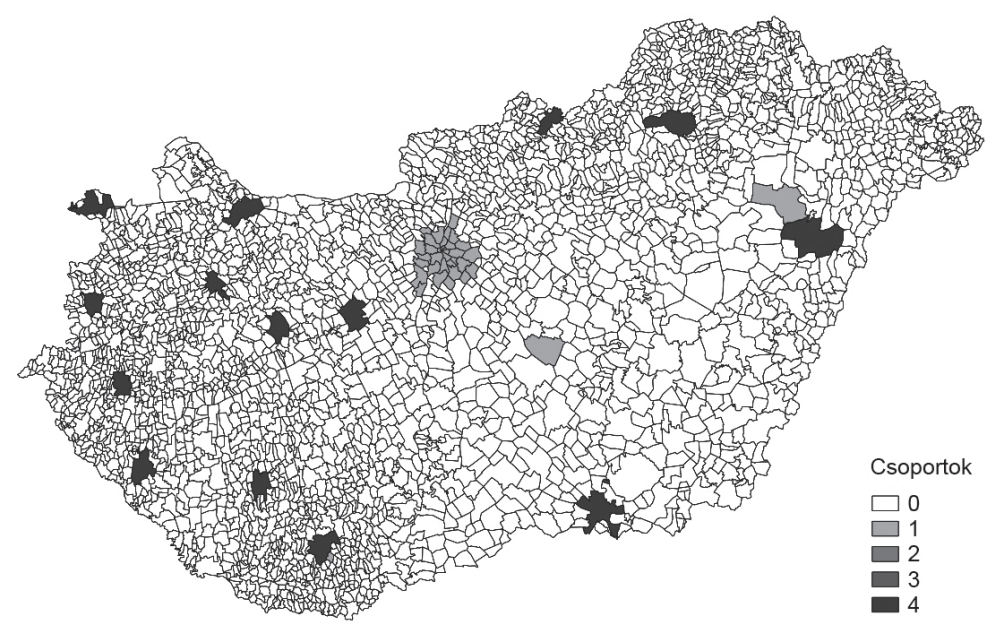

3. ábra

A magyar bankfiókok csoportokba rendeződése a lokális Moran's I statisztika számított értékei alapján (2020)

Forrás: MNB alapján saját számítás 
A 4. ábrán a magyarországi bankfiók-elhelyezkedés hot- és cold spotjai láthatók a Getis-Ord G* elemzés eredményei szerint. 1697 település esetén nem volt szignifikáns hot- vagy cold spot észlelhető, míg 110 település esetén hot-, 1366 település esetén cold spotról beszélhetünk.

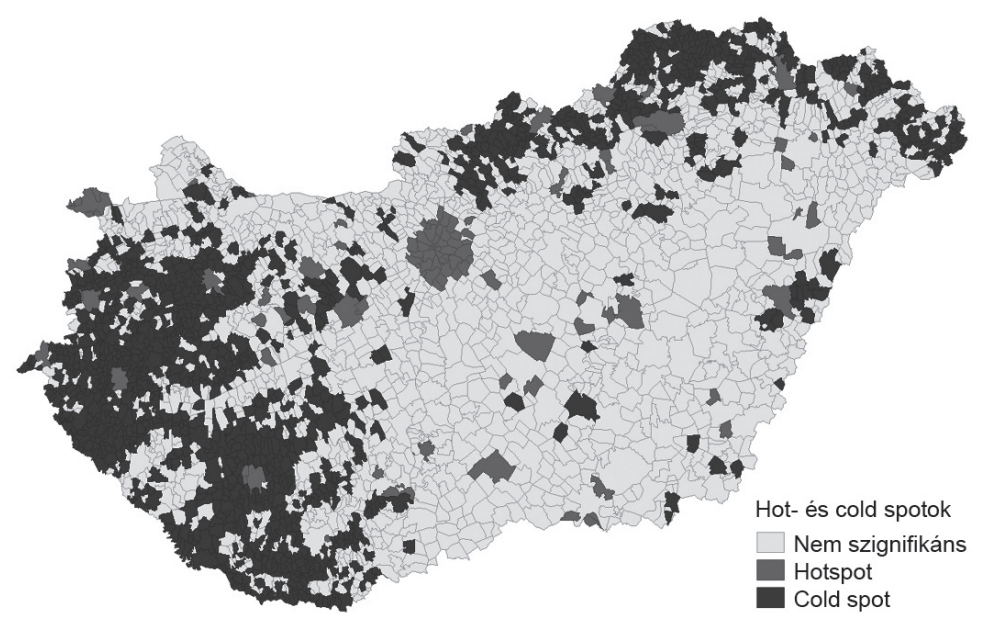

4. ábra

Hotspotok és cold spotok a magyarországi bankfiókhálózat térszerkezetében (2020)

Forrás: MNB alapján saját számítás

Jól kirajzolódik, hogy hasonlóan a lokális Moran's I-hez, ez esetben is kiemelkedik Budapest és környéke, amelyet egy kiterjedt hotspot fed le. Ezenkívül csak kisebb, jellemzően a nagyvárosokat tartalmazó hotspotok láthatók, amelyek sokkal kevésbé kiterjedtek, mint ami a fóváros esetében tapasztalható. A cold spotokat illetően, a Dunántúl kisebb községeinek és városainak jelentős része cold spotnak számít, valamint az északkeleti határszakasz mentén figyelhetők meg további cold spotok, amelyeket jelentős részben aprófalvas térségek, esetleg kisebb városok alkotnak. Mindkét jelentős kiterjedésű cold spot térség esetében megfigyelhető, hogy a régió nagyobb városai jelentenek hotspotot a bankfiókszámokat tekintve, ez főleg a Dunántúl esetében szembetűnő. Ezekből úgy tűnik, hogy ezekben a régiókban a bankok stratégiája a régió központjában való megjelenés, ahonnan a környék községeit, kisvárosait kívánják kiszolgálni, anélkül, hogy bankfiókkal is kitelepülnének ezekbe a térszegmensekbe.

\section{Konklúzió}

A jelen vizsgálat célja a magyarországi településeken lévő bankfiókok térszerkezeti mintázatának több szempontú vizsgálata, amelynek keretében az elemzés képet adott arról, hogy melyek azok a települések, térségek, amelyek bankfiókokkal jobban és kevésbé ellátottak, és hogy ezek a térben hogyan viszonyulnak egymáshoz. A tanulmányban a területi autokorreláció témakörében használatos mérőszámokat használtuk fel, 
globális és lokális Moran's I statisztika és Getis-Ord-féle G* mutatószámokon alapuló vizsgálatok készültek. Az eredmények rámutatnak, hogy települési szinten elemezve a bankfiókok elhelyezkedése területileg pozitívan autokorrelál, a települések bankfiókszámot tekintve klaszterekbe rendeződnek. Az elemzés eredményei alapján az rajzolódik ki, hogy Budapest és annak vonzáskörzete bankfiókszám-szempontból egy nagyobb csomópontnak számít, amelyhez hasonló az ország egyéb területein nem található. A magyarországi megyeszékhelyeknek, amelyek önmagukban az országos átlaghoz képest jelentősebb számú bankfiókkal rendelkeznek, egyedi a helyzetük, mert esetükben nem jellemző a fővároshoz hasonló bankfiókokkal ellátott vonzáskörzet megléte, sokkal inkább egy-egy kiugró elemként jelennek meg saját térségüket, megyéjüket tekintve. Az ország két régiójában tapasztalható a bankfiókok számát tekintve jelentősebb lemaradás az országos átlagtól: a Dunántúli térség számottevő része (jellemzően Nyugatés Dél-Dunántúl régió kis községei, kisvárosai), valamint az északkeleti határszakasz menti települések azok, amelyek két nagy, lényegében összefüggő bankfiókszempontból gyengén lefedett területet jelölnek ki. A kutatás eredményei összecsengenek a szakirodalom eredményeivel, klaszterezett, területileg pozitívan autokorrelált a bankfiókok elhelyezkedése. A jelen kutatás megalapozását adja azon további munkáknak, amelyek tárgya annak vizsgálata, hogy a bankfiókok elhelyezkedésének melyek a fő hatótényezői. Ennek megválaszolása a településekre jellemző társadalmi, gazdasági és bankpiaci jellemzők figyelembevételével történhet, amelyek a bankfiókelhelyezési döntéseknek fontos elemei lehetnek.

\section{Felhasznált irodalom}

Alpek, B. Levente - Róbert Tésits - László Bokor: Group-specific analysis of commuting in the most disadvantaged areas of Hungary. Regional Statistics, 6. (2016), 1. 54-81. Online: https://mpra.ub.uni-muenchen.de/74499/

American Bankers Association: A Guide to Selecting Bank Locations. A.B.A. Marketing Research Aids Series Number 2. New York, American Bankers Association, 1968.

Anselin, Luc: Local Indicators of Spatial Association-LISA. Geographical Analysis, 27. (1995), 2. 93-115. Online: https://doi.org/10.1111/j.1538-4632.1995.tb00338.x Anselin, Luc - Ibnu Syabri - Youngihn Kho: GeoDa: An introduction to spatial data analysis. Geographical Analysis, 38. (2006), 1. 5-22. Online: https://doi.org/10.1111/ j.0016-7363.2005.00671.x

Ansong, David - Gina Chowa - Bernice Korkor Adjabeng: Spatial analysis of the distribution and determinants of bank branch presence in Ghana. International Journal of Bank Marketing, 33. (2015), 3. 201-222. Online: https://doi.org/10.1108/IJBM09-2013-0103

Bhattacharya, Joydeep: The role of foreign banks in developing countries: a survey of the evidence. Working Paper, Ames, Iowa, 1994. Online: www2.econ.iastate.edu/faculty/ bhattacharya/foreignbankspaper.pdf

Bod’a, Martin - Katarína Čunderlíková: Determinants of bank branch density: A case study of Slovakia. International Journal of Bank Marketing, 38. (2020), 4. 933-959. Online: https://doi.org/10.1108/IJBM-07-2019-0267 
Burgstaller, Johann: Dynamics of Retail-Bank Branching in Austria. Economic Notes, 46. (2017), 3. 527-554. Online: https://doi.org/10.1111/ecno.12087

Chang, Angela - Shubham Chaudhuri - Jith Jayaratne: Rational herding and the spatial clustering of bank branches: An empirical analysis. Columbia University Department of Economics Discussion Papers, 9697-24. (1997), 1-34. Online: https://doi. org/10.7916/D8DF73DH

European Central Bank: Statistical Data Warehouse - SSI - Banking Structural Financial Indicators. 2020. Online: https://sdw.ecb.europa.eu/browse.do? node=9689719

Esperanca, José P. - Mohamed A. Gulamhussen: (Re)Testing the 'follow the customer' hypothesis in multinational bank expansion. Journal of Multinational Financial Management, 11. (2001), 3. 281-293. Online: https://doi.org/10.1016/S1042-444X (01)00027-5

Gál Zoltán: The development and the polarised spatial structure of the Hungarian banking system in a transforming economy. In Barta Györgyi - Fekete G. Éva - Szörényiné Kukorelli Irén - Timár Judit (eds.): Hungarian Spaces and Places: Patterns of Transition. Pécs, Centre for Regional Studies of the Hungarian Academy of Sciences, 2005. 197-219. Online: www.regscience.hu:8080/xmlui/handle/11155/327

Getis, Arthur - Keith J. Ord: The analysis of spatial association by use of distance statistics. Geographical Analysis, 24. (1992), 3. 189-206. Online: https://doi.org/10.1 111/j.1538-4632.1992.tb00261.x

Getis, Arthur - Keith J. Ord: Local spatial statistics: an overview. In Paul Longley - Michael Batty (eds.): Spatial Analysis: Modelling in a GIS Environment. John Wiley \& Sons, 1996. 261-277.

Grubel, Herbert: A theory of multinational banking. PSL Quarterly Review, 30. (1977), 123. 349-363. Online: https://ojs.uniroma1.it/index.php/PSLQuarterlyReview/ article/view/11510

Hopmans, Anton C. M.: A spatial interaction model for branch bank accounts. European Journal of Operational Research, 27. (1986), 2. 242-250. Online: https://doi. org/10.1016/0377-2217(86)90066-4

Kovács Sándor Zsolt: Város-vidék-kapcsolat a magyar pénzintézethálózatban. Területi Statisztika, 57. (2017), 5. 495-511. Online: www.ksh.hu/docs/hun/xftp/terstat/ 2017/05/ts570502.pdf

Központi Statisztikai Hivatal: Digitális gazdaság és társadalom, 2018. Budapest, 2018. Online: www.ksh.hu/docs/hun/xftp/idoszaki/ikt/ikt18.pdf

Magyar Nemzeti Bank: Pénzügyi Stabilitási Jelentés (2019. május). Budapest, 2019. Online: www.mnb.hu/letoltes/penzugyi-stabilitasi-jelentes-2019-majus.pdf

Magyar Nemzeti Bank: P56-os „Pénzforgalmat bonyolító hálózati egységek és ATM-ek elhelyezkedésére, valamint a nyújtott szolgáltatásokra vonatkozó adatok” adatszolgáltatás, 2020.

Moran, Patrick A. P.: The interpretation of statistical maps. Journal of the Royal Statistical Society. Series B, 10. (1948), 2. 243-251. Online: https://doi.org/10.1111/j.2517 -6161.1948.tb00012.x

Okeahalam, Charles: Bank branch location: a count analysis. Spatial Economic Analysis, 4. (2009), 3. 275-300. Online: https://doi.org/10.1080/17421770903114695 
Ord, Keith J.- Getis Arthur: Local spatial autocorrelation statistics: distributional issues and an application. Geographical Analysis, 27. (1995), 4. 286-306. Online: https:// doi.org/10.1111/j.1538-4632.1995.tb00912.x

Qi, Shusen - Ralph De Haas - Steven Ongena - Stefan Straetmans: Move a little closer? Information sharing and the spatial clustering of bank branches. EBRD Working Paper, (2018), 223. 1-55. Online: https://doi.org/10.2139/ssrn.3291522

Szakálné Kanó Izabella: A gazdasági aktivitás térbeli eloszlásának vizsgálati lehetőségei. Statisztikai Szemle, 89. (2011), 1. 77-100. Online: www.ksh.hu/statszemle_arch ive/2011/2011_01/2011_01_077.pdf

Temesvary, Judit: Some determinants of commercial bank behavior. Doctoral Dissertation, Faculty of the Graduate School of Cornell University, Degree of Doctor of Philosophy, 2011. Online: https://ecommons.cornell.edu/handle/1813/30674

Tóth Géza: Területi autokorrelációs vizsgálat a Local Moran I módszerével. Tér és Társadalom, 17. (2003), 4. 39-49. Online: https://doi.org/10.17649/TET.17.4.914

Tóth Géza - Kincses Áron: A mai magyarországi bevándorlás térbeli autokorreláltsága. Földrajzi Közlemények, 135. (2011), 1. 83-91. Online: www.foldrajzitarsasag.hu/ downloads/foldrajzi_kozlemenyek_2011_135_evf_1_szam.pdf

Walter, Ingo F.: Global Competition in Financial Services: Market Structure, Protection, and Trade Liberalization. Cambridge, MA, Ballinger, 1988.

Willer, David J.: A Spatial Decision Support System for Bank Location: A Case Study. Technical Report 90-9, 1990. Online: http://citeseerx.ist.psu.edu/viewdoc/download?doi=10.1.1.471.878\&rep=rep1\&type=pdf 